Ks. Wojciech Zyzak

\title{
TEOLOGICZNO-DUCHOWY WYMIAR MILOSIERDZIA W ŚWIETLE BULLI MISERICORDIAE VULTUS PAPIEŻA FRANCISZKA
}

\section{Wstęp}

Papież Franciszek, ogłaszając 11 kwietnia 2015 roku Nadzwyczajny Jubileusz Miłosierdzia, za tytuł bulli obrał słowa Misericordiae Vultus, odwołujące się do Oblicza Miłosierdzia. W chrześcijańskiej tradycji Oblicze Miłosierdzia przedstawiano głównie jako wizerunek Chrystusa czy to stojącego w grobie i ukazującego ślady męki w motywie Misericordia Domini, czy w koronie cierniowej z ewangelicznej sceny Ecce Homo (J 19, 5) ${ }^{1}$. Jednak najbardziej znane Oblicze Miłosierdzia widnieje na obrazie zmartwychwstałego Pana z podpisem Jezu, ufam Tobie, sporządzonym według wizji świętej Faustyny Kowalskiej². Jeśli, idąc za intuicją francuskiego filozofa Emmanuela Lévinasa, możemy powiedzieć, że twarz otwiera na wymiar tego, co boskie, to oblicze Chrystusa staje przed nami jako najdoskonalsze objawienie miłosiernego Boga. Jednak w filozofii dialogu każda ludzka twarz umożliwia głębokie wewnętrzne spotkanie z drugim i ukazuje się w wymiarze etycznym ${ }^{3}$. Troska i odpowiedzialność za bliźniego przez wieki znajdowały w chrześcijaństwie wyraz w wizji uczynków miłosiernych co do ciała (por. Mt 25, 31-46), przy czym czasami odznaczający się szczególnym miłosierdziem święci przedstawiani są na wizerunkach jako pomagający, zaś Chrystus zajmuje miejsce

\footnotetext{
1 Por. Parafia Narodzenia św. Jana Chrzciciela w Korzkwi, red. Z. Płachta, Kraków 2012,

2 Por. A. Witko, Obraz Bożego Miłosierdzia, Kraków 2004; J. Zabielski, Wydobywanie dobra. Teologia chrześcijańskiego miłosierdzia, Białystok 2006, s. 166n.

3 Por. M. Pluta, Emmanuela Lévinasa etyka odpowiedzialności, „Łódzkie Studia Teologiczne" 7 (1998), s. 137n.
} s. 19. 
potrzebującego ${ }^{4}$. Szczególnie od pontyfikatu świętego Jana Pawła II, który ogłosił encyklikę Dives in misericordia i kanonizował Faustynę Kowalską, oba aspekty miłosierdzia Bożego i ludzkiego znajdują się w centrum teologiczno-duchowej dyskusji ${ }^{5}$. Kardynał Walter Kasper sugeruje, że do refleksji na ten temat skłania szczególnie dramat drugiej wojny światowej ${ }^{6}$. Jednak papież Franciszek przypomina, że współczesny świat wciąż pełen jest podobnych dramatów, które na nowo każą postawić pytanie o Boże i ludzkie miłosierdzie.

\section{Chrystus objawieniem miłosierdzia Ojca}

Jak już wyżej wspomniano, współcześnie kult Bożego miłosierdzia wiąże się głównie z obrazem Jezu, ufam Tobie ${ }^{7}$. Obraz ten jest syntezą, a zarazem symbolem całego orędzia o Bożym miłosierdziu, które Bóg przekazał przez siostrę Faustynę. Ukazując wcielone Słowo, wizerunek plastycznie wyraża ewangeliczne orędzie o miłosiernej miłości Boga do człowieka, opisane w Bibliii ${ }^{8}$. W Nowym Testamencie miłosierdzie jest ujmowane przez pryzmat osoby i dzieła Jezusa Chrystusa, zwłaszcza Jego misterium paschalnego ${ }^{9}$. Dlatego papież Franciszek w bulli stwierdza, że „Jezus Chrystus jest obliczem miłosierdzia Ojca” ${ }^{10}$. Wcześniej, zarówno Dzienniczek siostry Faustyny, jak również encyklika Jana Pawła II Dives in misericordia wskazały na wydarzenia z życia Jezusa, czyli Jego wcielenie, słowa i czyny, krzyż, śmierć i zmartwychwstanie, jako na zasadniczy wyraz Bożego miłosierdzia względem człowieka ${ }^{11}$. Papież Franciszek w omawianej bulli położył akcent na misterium paschalnym:

Podczas gdy Jezus odprawiał po raz pierwszy Eucharystię, jako Wieczną Pamiątkę swojej realnej obecności pomiędzy nami, umiejscawiał symbolicznie ten najwyższy akt Objawienia w świetle miłosierdzia. W tymże samym horyzoncie miłosierdzia

4 Por. K. S. Frank, Barmherzigkeit, VI: Ikonographisch, [w:] Lexikon für Theologie und Kirche, t. 2, Freiburg im Breisgau 2006, k. 17; C. Schweicher, Barmherzigkeit, Werke der, [w:] Lexikon der christlichen Ikonographie, t. 1, Freiburg im Breisgau 1994, k. 245-251.

5 Por. J. Zabielski, Wydobywanie dobra..., dz. cyt., s. 11.

6 Por. W. Kasper, Miłosierdzie. Klucz do chrześcijańskiego życia, Poznań 2014, s. 7-12.

7 Por. J. Zabielski, Wydobywanie dobra..., dz. cyt., s. 166n.

8 Por. N. Chmura, Miłosierne oblicze Boga w znaku obrazu Jezu Ufam Tobie!, „Łódzkie Studia Teologiczne" 24 (2015) 4, s. 28.

9 Por. A. Słomkowski, Miłosierdzie Boże we Wcieleniu i Odkupieniu, [w:] Ewangelia Miłosierdzia, red. W. Granat, Poznań 1970, s. 49-112; I. Broer, Barmherzigkeit, I: Biblisch, [w:] Lexikon für Theologie und Kirche, t. 2, dz. cyt., k. 14n.

10 Franciszek, Misericordiae Vultus, Wrocław 2015, 1 [dalej: MV].

11 Por. M. Jodko, Encyklika „Dives in misericordia” w kontekście Dzienniczka św. Faustyny Kowalskiej, „Łódzkie Studia Teologiczne” 24 (2015) 4, s. 36-40. 
Jezus przeżywał swoją mękę i śmierć, świadomy wielkiej tajemnicy miłości, która wypełniła się na krzyżu².

Wydaje się, że dla papieża Franciszka szczególne znaczenie ma aspekt Bożego miłosierdzia objawiającego się w spojrzeniu Chrystusa. W nawiązaniu do ewangelicznej sceny powołania Mateusza (por. Mt 9, 9-13), papież sięgnął do komentarza świętego Bedy Czcigodnego, który stwierdził, że Jezus spojrzał na celnika z „uczuciem miłości i wybrał go" (miserando atque eligendo). Te słowa zrobiły na ojcu św. tak wielkie wrażenie, że, jak przypomniał w bulli, wybrał je na swoje biskupie zawołanie. Takie spojrzenie spowodowało nawrócenie Piotra (por. Łk 22, 61). Wątek zaparcia się prowadzi naszą refleksję na nowo do kontekstu tajemnicy paschalnej. Chrystus w wieczerniku zapowiedział uczniom: „Jeden z was mnie zdradzi” (Mt 26, 21). Mówiąc o zdradzie jednego z uczniów, nie chodziło Mu zapewne o zaparcie się go, jak w przypadku Piotra. Mogło chodzić o srebrniki, ale jeszcze bardziej prawdopodobne wydaje się zwątpienie w miłosierdzie Jezusa. W świetle całego przesłania ewangelicznego takie zwątpienie wydaje się być prawdziwą zdradą Chrystusa. Tym bardziej że dla papieża Franciszka głęboki sens miłosierdzia znajduje się w Jezusowych przypowieściach o przebaczeniu. W bulli czytamy: „Znamy te przypowieści, a szczególnie trzy z nich: przypowieść o zaginionej owcy, o zagubionej monecie i o synu marnotrawnym (por. Łk 15, 1-32). W tych przypowieściach Bóg zawsze przedstawiony jest jako pełen radości, przede wszystkim, gdy przebacza"13. Przykład i ofiara wcielonego Miłosierdzia nadają najgłębszy sens pojęciu Bożego miłosierdzia przedstawionego już w sposób jasny i właściwie pełny na kartach Starego Testamentu ${ }^{14}$.

\section{Miłosierdzie jako przymiot Boga}

Zarówno w Starym, jak i Nowym Testamencie Bóg objawił się jako miłosierny ${ }^{15}$. Papież Franciszek w bulli przytoczył komentarz św. Augustyna do Psalmu 76, w którym stwierdził, że „łatwiej jest Bogu powstrzymać gniew, aniżeli miłosierdzie" ${ }^{16}$. Mistycy, by wyrazić prawdę o Bożym miłosierdziu, często posługiwali się metaforycznymi obrazami. W Dzienniczku siostry Faustyny są to głównie me-

12 MV, 7.

13 Tamże, 9.

14 Por. J. Homerski, Miłosierdzie w księgach Starego Testamentu, [w:] Homo Meditans, t. 5: Miłosierdzie w postawie ludzkiej, red. W. Słomka, Lublin 1989, s. 26.

15 Por. J. Zabielski, Wydobywanie dobra..., dz. cyt., s. 52n; E. Salmann, Barmherzigkeit, II: Systematisch-theologisch, [w:] Lexikon für Theologie und Kirche, t. 2, dz. cyt., k. 15.

16 MV, 21. Por. Augustyn z Hippony, Enarrationes in Psalmos 76, 11. 
tafory wodne, przestrzenne, świetlne i wskazujące na atrybuty królewskie ${ }^{17}$. Niemniej jednak dla papieża Franciszka miłosierdzie Boga nie jest jakąś abstrakcyjną ideą, ale konkretnym faktem, dzięki któremu On objawia swoją miłość ojcowską i matczyną, która „wypływa z wnętrzności” i zwraca się do dziecka. Zwrócenie w bulli uwagi na wnętrzności i na matczyną miłość Boga skłania do głębszych analiz metaforyki miłosierdzia. W Dzienniczku siostra Faustyna używa wyrażenia „łono” przynajmniej 14 razy i zawsze chodzi o łono Boga w Trójcy Jedynego. Zwrot ten jest w jej języku całkowicie podporządkowany miłosierdziu Bożemu ${ }^{18}$. Warto w tym kontekście sięgnąć do analizy terminologii biblijnej zarówno Starego, jak i Nowego Testamentu. Pośród różnych terminów związanych z miłosierdziem szczególnie bliski ojcu św. wydaje się rdzeń רחם (raham), który oznacza współczucie oraz płynące $\mathrm{z}$ niego okazywanie pełnej miłości i przychylności. W formie rahamim wskazuje się na miłość bardziej matczyną, skoro stanowi liczbę mnogą od słowa „łono”. Z największej pierwotnej bliskości, jaka łączy matkę z dzieckiem, wynika szczególny charakter relacji darmowej miłości. Chodzi tu o postawę naznaczoną emocjonalnością, czułością, tkliwością i wyrozumiałością. W Nowym

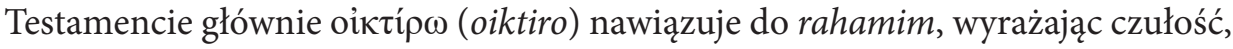
wzruszenie i serdeczne współczucie ${ }^{19}$.

Tak rozumiane Boże miłosierdzie nie jest zdaniem papieża Franciszka przejawem jakiejś słabości, ale wszechmocy Boga. Na poparcie tej tezy cytuje on wielkiego teologa średniowiecznego św. Tomasza z Akwinu: „Właściwe Bogu jest stosowanie miłosierdzia i w tym najwyraźniej wyraża się jego wszechmoc" ${ }^{20}$. Zgodnie $\mathrm{z}$ zasadą lex orandi, lex credendi, znajduje to wyraz w liturgii, gdzie jedna z najstarszych kolekt przywołuje następujące słowa modlitwy: „Boże, Ty przez przebaczenie i litość najpełniej okazujesz swoją wszechmoc”. Trzeba jednak pamiętać, że dla wspomnianego przez papieża Franciszka Tomasza z Akwinu miłosierdzie Boga jest przymiotem, a nie tylko stanem współczującego umysłu ${ }^{21}$. Co więcej, w objawieniach św. Faustyny Kowalskiej miłosierdzie jest określone jako „największy

17 Por. I. Rutkowska, Pojęcie miłosierdzia w Dzienniczku św. Faustyny Kowalskiej, „Łódzkie Studia Teologiczne" 24 (2015) 4, s. 78.

18 Por. M. Bernyś, Znaczenie Miłosierdzia Bożego w powołaniu kapłana, „,ódzkie Studia Teologiczne" 24 (2015) 4, s. 17.

19 Por. J. Zabielski, Wydobywanie dobra..., dz. cyt., s. 20n, 53, 60-63; W. Słomka, Miłosierdzie Boże, [w:] Leksykon Duchowości Katolickiej, Lublin-Kraków 2002, s. 522; J. Upton, Mercy, [w:] The New Dictionary of Catholic Spirituality, Collegeville 1993, s. 653n; J. Machniak, Doświadczenie Boga w tajemnicy Jego miłosierdzia u Bł. Siostry Faustyny Kowalskiej, Kraków 1998, s. 15; R. Ukleja, Miłosierdzie Boże z pokolenia na pokolenie, Wrocław 1997, s. 18n. Szerzej na ten temat pisze S. Hałas, Biblijne słownictwo miłości i miłosierdzia na zderzeniu kultur, Kraków 2011. Por. W. Misztal, Miłosierne Oblicze Boga: świadectwo Biblii, „Łódzkie Studia Teologiczne" 24 (2015) 4, s. 57.

${ }_{20}$ MV, 6. Por. Tomasz z Akwinu, Summa theologica, II-II, q. 30, a. 4.

21 Por. Tomasz z Akwinu, Summa theologica, I, q. 21, a. 3. 
przymiot Boga"22 . Oczywiście, miłosierdzie jako doskonałość Boga, w którym wszystkie przymioty stanowią Jego istotę, jest równe sprawiedliwości, mądrości, dobrotliwości i opatrzności. Jednak jako przymiot charakteryzujący działanie Boga jest największe, gdyż polega na udzielaniu się bytu najwyższego bytom niższym. Miłosierdzie jest największą doskonałością w bycie najwyższym, niemającym bytu nad sobą, któremu mógłby się poddać przez miłość. Jest to jasne w wypadku porównania z człowiekiem, którego istotę doskonałości i najwyższą cnotę stanowi miłość, łącząca z bytem najwyższym ${ }^{23}$. Scholastyka tradycyjnie odróżniała przymioty „wsobne”, należące do Boga jako bytu samego w sobie (niezłożoność, nieskończoność, wieczność, niezmienność), od „odnośnych”, które ujawniają się w Bożych dziełach wobec stworzeń (mądrość, dobrotliwość, opatrzność, sprawiedliwość, miłosierdzie). Przez analogię do duchowych władz człowieka mówiono, że przymioty mądrości i opatrzności mają swoje miejsce w umyśle Boga, zaś dobrotliwość, sprawiedliwość i miłosierdzie związane są z Jego wolą. Miłosierdzie jest tu ujmowane jako udzielanie przez Boga dobra człowiekowi, by go wyprowadzić ze słabości i braków ${ }^{24}$. Tak więc miłosierdzie to niczym niezasłużone i wolne zwrócenie się Boga ku stworzeniu, czyli nie tyle przymiot istoty Boga, co pokrewny z łaską, ujmowany $\mathrm{z}$ historiozbawczej perspektywy wyraz Jego istotowej miłości. Bóg manifestuje swe miłosierdzie, zwracając się swą bliskością ku cierpiącym i swą przebaczającą przychylnością ku grzesznikom. Przez to miłosierdzie pozostaje w relacji pewnego napięcia do sprawiedliwości. Jeśli sprawiedliwość oddaje każdemu, co mu się należy, to oczywiste jest, że takie oddanie ze strony Boga zawsze jest niezasłużone i płynie z miłosierdzia, które jest miarą sprawiedliwości ${ }^{25}$.

\section{Miłosierdzie w praktyce Kościoła}

Owocem tajemnicy paschalnej jest Kościół, który nie tylko głosi i wyznaje Boże miłosierdzie, nie tylko stara się je przywoływać i naśladować, ale także je urzeczywistnia i uobecnia jako sakrament zbawienia, czyli okazywanego wciąż światu Bożego miłosierdzia ${ }^{26}$. Papież Franciszek wyraził to słowami: „Jezus stwierdza, że miłosierdzie to nie jest tylko działanie Ojca, lecz staje się kryterium potrzebnym

22 W. Słomka, Miłosierdzie Boże..., dz. cyt., s. 523.

23 Por. Tomasz z Akwinu, Summa theologica, II-II, q. 30, a. 4, c; J. Machniak, Doświadczenie Boga..., dz. cyt., s. 19.

24 Por. J. Machniak, Doświadczenie Boga..., dz. cyt., s. 16.

25 Por. E. Salmann, Barmherzigkeit, dz. cyt., k. 15.

26 Por. L. Balter SAC, Kościót jako sakrament Bożego Miłosierdzia, [w:] Bóg bogaty w miłosierdzie, red. L. Balter, S. Dusza, A. Piętka, Poznań 2003, s. 173. 
do zrozumienia, kim są Jego prawdziwi synowie. Jesteśmy więc wezwani do życia miłosierdziem, ponieważ to nam zostało najpierw udzielone miłosierdzie"27.

Rzeczywiście, prawda o Bożym miłosierdziu jest centralnym elementem misji, jaką uczniowie Chrystusa otrzymali od swego Pana. Misja ta realizuje się przez głoszenie miłosierdzia Bożego w liturgii słowa, sprawowanie Eucharystii i sakramentu pokuty. Miłosierdzie doświadczone od Boga otwiera na możliwość dzielenia się nim ${ }^{28}$. Najpierw refleksja eklezjologiczna znajduje pogłębienie w sakramentologii, gdyż analizując naturę sakramentu, czyli wydarzenia Chrystusa uobecnianego w liturgii, dochodzi się do tajemnicy Ojca miłosierdzia ${ }^{29}$. Dotyczy to szczególnie chrztu, Eucharystii i sakramentu pojednania, w którym dokonuje się spotkanie z Chrystusem miłosiernym i przebaczającym grzechy ${ }^{30}$. Nie bez powodu Ordo paenitentiae z 1974 roku zaczyna się pierwszymi słowami rozgrzeszenia: „Bóg Ojciec miłosierdzia” ${ }^{31}$. Właśnie w przebaczeniu najbardziej objawia się miłosierna miłość Boga do człowieka. Miłosierdzie wyrażające się w odpuszczeniu grzechów jest też najbardziej oczywistym dowodem Bożej wszechmocy ${ }^{32}$. Dlatego papież Franciszek w bulli twierdził: „Z przekonaniem na nowo kładziemy w centrum sakrament pojednania, ponieważ pozwala dotknąć nam wielkość miłosierdzia" ${ }^{33}$. Papieże ostatnich dziesięcioleci, w tym szczególnie św. Jan Paweł II, przypominali wielką rolę kapłana, szafarza sakramentu miłosierdzia, który jako pierwszy winien z tego daru korzystaćc ${ }^{34}$. Papież Franciszek w Roku Świętym dołączył do tego jeszcze posługę misjonarzy miłosierdzia i przypomniał Kościołowi o znaczeniu odpustu:

W sakramencie pojednania Bóg przebacza grzechy, które zostają naprawdę zgładzone, lecz jednak negatywny ślad, który grzechy zostawiły w naszym postępowaniu i w naszych myślach pozostaje. Miłosierdzie Boże jest jednakowoż silniejsze również niż ten ślad. Staje się ono odpustem Ojca, który poprzez Kościół - Oblubienicę Chrystusa - dosięga grzesznika, któremu udzielił już przebaczenia i uwalnia go od każdej

$27 \mathrm{MV}, 9$.

28 Por. J. Machniak, Miłosierdzie Boże w nauczaniu Ojca Świętego Jana Pawła II, „Łódzkie Studia Teologiczne" 24 (2015) 4, s. 52.

29 Por. N. Bux, Miłosierne działanie Trójcy Świętej w sakramentach, [w:] Bóg bogaty w miłosierdzie, dz. cyt., s. 196.

30 Por. S. Mojek, Miłosierdzie Boże w sprawowaniu sakramentu pojednania, [w:] Homo Meditans, t. 5, dz. cyt., s. 130-134.

31 Por. J. Servais, Spowiedź sakramentem Ojca Miłosierdzia. Profetyczna intuicja Adrienne von Speyr, [w:] Bóg bogaty w miłosierdzie, dz. cyt., s. 210.

${ }_{32}$ Por. Tomasz z Akwinu, Summa theologica, I, q. 25, a. 3, ad 3; J. Machniak, Doświadczenie Boga..., dz. cyt., s. 20n.

${ }_{33} \mathrm{MV}, 17$.

34 Por. Jan Paweł II, Dar i Tajemnica, Kraków 1996, s. 84. 
pozostałości skutków grzechu, umożliwiając mu raczej działanie z miłością oraz wzrastanie w miłości, niż ponowny upadek w grzech $^{35}$.

Ukazane wyżej doświadczenia duchowe otwierają człowieka na praktykowanie miłosierdzia w relacji do bliźnich. W tym ujęciu miłosierdzie jest formą miłości, która spontanicznie zwraca się ku drugiemu znajdującemu się w potrzebie pomocy. Człowiek miłosierny cierpi i solidaryzuje się z bliźnim oraz stara się oddalić wszystko, co uniemożliwia jego rozwój. Warto przypomnieć, że święty Tomasz z Akwinu przyznał miłosierdziu status cnoty moralnej. Choć jej przedmiotem są uczucia, pochodzi ona ze sprawności intelektualno-wolitywnej i jest bliska miłości, posiadając odmienną pobudkę w postaci nędzy człowieka. Oczywiście ostateczną racją miłosierdzia nie są niedole, lecz naśladowanie miłosierdzia Boga oraz godność osoby ludzkiej. Nie można redukować miłosierdzia do jałmużny, choć praktyka uczynków miłosierdzia ma olbrzymie, nie tyle teologiczne, co życiowe znaczenie. Zgodnie z Ewangelią (por. Mt 25, 31-46) będą one stanowić kryterium sądu Bożego. Tradycja wypracowała po siedem uczynków względem ciała i duszy $^{36}$. O ich znaczeniu pisał papież Franciszek w bulli:

Jest moim gorącym życzeniem, aby chrześcijanie przemyśleli podczas Jubileuszu uczynki miłosierdzia względem ciała i względem ducha. Będzie to sposobem na obudzenie naszego sumienia, często uśpionego w obliczu dramatu ubóstwa, a także umożliwi nam coraz głębsze wejście w serce Ewangelii, gdzie ubodzy są uprzywilejowani dla Bożego miłosierdzia ${ }^{37}$.

Papież przypomniał też słowa św. Jana od Krzyża: „Pod wieczór życia będą cię sądzić z miłości” ${ }^{38}$.

Kościół przez całą swoją historię organizował różne formy miłosierdzia, od posługi diakonów i pomocy materialnej siostrzanym wspólnotom, przez charytatywną działalność zakonów, bractw i szpitali w średniowieczu, aż po współczesne działania organizacji Caritas ${ }^{39}$. Tak więc historia zna wiele modeli chrześcijańskiego miłosierdzia. W naszych czasach wydaje się, że św. Faustyna Kowalska i św. Jan Paweł II wypracowali nowy model, który teologowie określają jako model

$35 \mathrm{MV}, 22$.

36 Por. Tomasz z Akwinu, Summa theologica, II-II, q. 30, a. 3; J. Zabielski, Wydobywanie dobra..., dz. cyt., s. 80, 83n; A. Elsässer, Barmherzigkeit, III: Theologisch-ethisch, [w:] Lexikon für Theologie und Kirche, t. 2, dz. cyt., k. 15n; B. Ferdek, Miłosierdzie, [w:] Leksykon Duchowości Katolickiej, dz. cyt., s. 518n.

37 MV, 15.

38 Tamże. Por. Jan od Krzyża, Słowa światła i miłości, 59.

39 Por. B. Ferdek, Miłosierdzie, dz. cyt., s. 519-522. 
personalistyczny, gdyż w akcie miłosierdzia na pierwszym miejscu jest godność człowieka, a potem jego potrzeby ${ }^{40}$. Jan Paweł II nauczał, że miłosierdzie jako akt miłości miłosiernej polega na wspólnym przeżyciu dobra, jakim jest osoba oraz na wspólnym doświadczeniu jej godności. Atrybutami tak rozumianego miłosierdzia są: współuczestnictwo w dobru osoby, wzajemność doświadczenia tego dobra, zrównanie osób przy zachowaniu ich ontycznej odrębności oraz wierność osobie. W pełnym i właściwym kształcie miłosierdzie urzeczywistnia się w odniesieniu Boga do człowieka, jednak w sposób analogiczny realizuje się w relacjach między ludźmi, którzy naśladują Boga „bogatego w miłosierdzie”41.

\section{Miłosierdzie a nowa ewangelizacja}

Współcześnie miłosierdzie traktuje się jako powołanie, nakładające rzeczywisty obowiązek. Obecnie stało się jasne, że w religijno-moralnym życiu i posłannictwie chrześcijanina miłosierna miłość winna stanowić normę postępowania ${ }^{42}$. Zauważono bowiem pewien związek przyczynowy między rozkwitem kultu Bożego miłosierdzia w XX wieku a współczesnymi wyzwaniami Kościoła i świa$\mathrm{ta}^{43}$. Wiąże się to bezpośrednio z zadaniem nowej ewangelizacji, o którym po raz pierwszy wspomniał Jan Paweł II 9 czerwca 1979 roku w Krakowie-Nowej Hu$\mathrm{cie}^{44}$. Odtąd on sam i jego następcy przypominali to zadanie stojące przed Kościołem. Temat ten podjął również papież Franciszek w bulli, pisząc:

Po rozbiciu murów, które przez zbyt długi czas trzymały Kościół w zamknięciu jak w uprzywilejowanej cytadeli, nadszedł czas na głoszenie Ewangelii w nowy sposób. Nowy etap ewangelizacji, która trwa od zawsze. Nowe zaangażowanie dla wszystkich chrześcijan, aby świadczyć z większym entuzjazmem i przekonaniem o swojej wierze ${ }^{45}$.

W tym kontekście wraz z rozwojem kultu Bożego miłosierdzia dostrzeżono potrzebę refleksji natury pastoralnej, starając się odpowiedzieć na pytanie, czy i dlaczego idea Bożego miłosierdzia może stanowić treść nowej ewangelizacji,

40 Por. E. Siepak, Święty człowiek o miłosiernym obliczu, „Łódzkie Studia Teologiczne” 24 (2015) 4, s. 96.

${ }^{41}$ Por. J. Zabielski, Wydobywanie dobra..., dz. cyt., s. 105.

42 Por. F. Greniuk, Czynić miłosierdzie drugim, [w:] Homo Meditans, t. 5, dz. cyt., s. 59.

${ }^{43}$ Por. W. Seremak SAC, Miłosierdzie Boże a nowa ewangelizacja. Znaki czasu, Lublin 2001, s. 398.

44 Por. Jan Paweł II, La croce di Nowa Huta, nuovo seme di evangelizzazione (9.06.1979), [w:] Insegnamenti di Giovanni Paolo II, II/1979, Libreria Editrice Vaticana 1979, s. 1505.

$45 \mathrm{MV}, 4$. 
a przez to przyczynić się do zaradzenia różnym zagrożeniom człowieka i ludzkości. Idea miłosierdzia Bożego jest tu postrzegana jako środek zaradczy na zagrożenia istniejące w dzisiejszym świecie. Ukazanie różnorakich zagrożeń, ale i godności człowieka, a przede wszystkim Bożego miłosierdzia, ma inspirować do głoszenia tej prawdy bliźnim. Jest więc ta idea motywem do zaangażowania się w dzieło ewangelizacji i do uczestnictwa w misji Kościoła. Skoro zasadniczą treść orędzia mesjańskiego Jezusa Chrystusa stanowi prawda o Bożym miłosierdziu, winna ona być inspirująca dla duszpasterstwa, szczególnie w wymiarze homiletycznym i katechetycznym ${ }^{46}$. Podkreślił to papież Franciszek, pisząc w bulli:

W naszym czasie, w którym Kościół jest zaangażowany w nową ewangelizację, temat miłosierdzia wymaga, by go ponownie przedstawić z nowym entuzjazmem i z odnowioną działalnością duszpasterską. Jest to kluczowe dla Kościoła oraz dla wiarygodności jego głoszenia, aby żył on i świadczył w pierwszej osobie o miłosierdziu ${ }^{47}$.

\section{Społeczny wymiar miłosierdzia}

Miłosierdzie stanowi nie tylko istotny wymiar w działaniu Kościoła, ale ma znaczenie ogólnoludzkie. Papież Franciszek w bulli zaznaczył, że „miłosierdzie posiada wartość, która przekracza granice Kościoła. Pozwala nam ono wejść w relacje $\mathrm{z}$ judaizmem i z islamem, które to religie uważają miłosierdzie jako jeden z najistotniejszych atrybutów Boga" ${ }^{48}$. Tak więc miłosierdzie charakteryzuje trzy wielkie religie monoteistyczne. Ma ono również wyraźny społeczny wymiar. Historia pokazuje, że tam, gdzie negowano wartości religijne, zanikał również wymiar ludzkiej solidarności. Konsekwencją zanegowania miłości miłosiernej w postawie ludzkiej jest zarówno nietzscheański immoralizm i egocentryzm, jak też marksistowska idea walki klas ${ }^{49}$. W ramach witalistyczno-biologicznej koncepcji życia niektórzy myśliciele już od starożytności odrzucali miłosierdzie, widząc w nim słabość, a nawet przeszkodę w rozwoju człowieka. Dla Fryderyka Nietzschego moralność oparta na idei miłosierdzia jest moralnością ludzi słabych, którym brak poczucia własnej wartości i dostojeństwa. Miłosierdzie jest więc w opinii filozofa oznaką upadku człowieka, zahamowaniem woli walki, nienawiści, okrucieństwa i siły ${ }^{50}$. Zbrodnie nazistowskie pokazały, do czego prowadzi

46 Por. W. Seremak SAC, Miłosierdzie Boże..., dz. cyt., s. 398.

$47 \mathrm{MV}, 12$.

48 Tamże, 23.

49 Por. S. Kowalczyk, Konsekwencja zanegowania miłości i miłosierdzia w postawie ludzkiej, [w:] Homo Meditans, t. 5, dz. cyt., s. 232-239.

50 Por. J. Zabielski, Wydobywanie dobra..., dz. cyt., s. 84n. 
w ostatecznej konsekwencji takie ujęcie miłosierdzia. Dlatego należy podkreślić, że zaangażowanie chrześcijan w posługę miłosierdzia poza wymiarem indywidualnym często przyjmuje także postać działalności społecznej i instytucjonalnej, tym cenniejszej, że wykonywanej dobrowolnie i nie dla $\mathrm{zysku}^{51}$.

Papież Franciszek jest świadom krytycznych opinii dotyczących miłosierdzia. W bulli cytował nauczanie św. Jana Pawła II z encykliki Dives in misericordia:

Umysłowość współczesna, może bardziej niż człowiek przeszłości, zdaje się sprzeciwiać Bogu miłosierdzia, a także dąży do tego, ażeby samą ideę miłosierdzia odsunąć ma margines życia i odciąć od serca ludzkiego. Samo słowo i pojęcie „miłosierdzie” jakby przeszkadzało człowiekowi, który poprzez nieznany przedtem rozwój nauki i techniki bardziej niż kiedykolwiek w dziejach stał się panem i uczynił sobie ziemię poddaną (por. Rdz 1, 28). Owo „panowanie nad ziemią", rozumiane nieraz jednostronnie i powierzchownie, jakby nie pozostawiało miejsca dla miłosierdzia ${ }^{52}$.

Tymczasem życie ludzkości musi rozwijać się na fundamencie żywej, powszechnej kultury moralnej. Dlatego demokracja nie powinna przyjmować wyłącznie ekonomicznego modelu produktywności i konsumpcjonizmu, ale podjąć nowe, wspólne wysiłki na rzecz budowy społeczności ludzkiej, umiejącej dzielić się dobrami materialnymi i duchowymi ${ }^{53}$. Bez miłosierdzia nie może być mowy o budowaniu i pogłębianiu cywilizacji miłości. Wobec ideologii nienawiści i walki klas chrześcijaństwo ukazuje prawdziwą równość i internacjonalizm wyrażony przez świętego Pawła w Liście do Galatów (por. Ga 3, 28). Dostrzegając grzeszność człowieka, wskazuje na tajemnicę miłosierdzia, z której płynie zobowiązanie, by w każdej sytuacji podać mu pomocną dłoń ${ }^{54}$.

Wraz z pojawieniem się w XIX wieku idei państwa opiekuńczego, gwarantującego bezpieczeństwo socjalne, zaczęło się wydawać, że miłosierdzie jako główna cnota społeczna straciło na znaczeniu. Odtąd miłosierdzie zaczęto kojarzyć z wyniosłością, fałszywą litością lub kamuflażem zaniedbanych reform strukturalnych. Zwłaszcza w marksizmie powtarzano, że ubodzy nie potrzebują pomocy charytatywnej, ale sprawiedliwości. Jest w tym coś z prawdy, choć trzeba dodać, że nawet tam, gdzie państwo zinstytucjonalizowało prawo do opieki socjalnej w szerokim zakresie, pozostaje wiele miejsca dla spontanicznej i ochoczej pomo-

51 Por. tamże, s. 171.

52 MV, 11. Por. Jan Paweł II, Dives in misericordia, 2.

53 Por. P. Warchoł, Miłosierny Bóg i miłosierny człowiek. Teologiczna interpretacja miłosierdzia w nauczaniu Jana Pawła II, Wrocław 2007, s. 265n.

54 Por. A. Nossol, Personalistyczno-humanistyczny aspekt $w$ doznawaniu $i$ świadczeniu miłosierdzia, [w:] Homo Meditans, t. 5, dz. cyt., s. 51. 
cy, której w wielu wypadkach nie da się niczym zastąpićs5. Do najważniejszych nieporozumień fałszujących wymiar miłosierdzia zaliczamy pozbawione społecznego odniesienia czysto indywidualistyczne lub jedynie duchowe jego rozumienie oraz przekonanie w zamożnych krajach, że uczynki miłosierdzia straciły na znaczeniu, poza pomocą krajom ubogim ${ }^{56}$. W tym kontekście papież Franciszek apelował w bulli:

Ileż sytuacji niepewności i cierpienia jest obecnych w dzisiejszym świecie! Ileż ran na ciele wielu, którzy nie mają już więcej głosu, ponieważ ich krzyk osłabł i zgasł z powodu obojętności bogatych narodów. W tym Jubileuszu Kościół zostanie jeszcze bardziej wezwany do leczenia tych ran, do opatrywania ich oliwą pocieszenia, do przewiązywania miłosierdziem oraz do leczenia ich solidarnością i należną uwagą ${ }^{57}$.

Ewangeliczny przykład miłosiernego Samarytanina nasuwa jako szczególnie przydatną w praktykowaniu miłosierdzia, charakterystyczną dla katolickiej nauki społecznej metodę: widzieć, ocenić, działać ${ }^{58}$.

\section{Miłosierdzie w życiu świętych}

Papież Franciszek w bulli Misericordiae Vultus poruszył jeszcze jeden istotny aspekt duchowości, mianowicie działanie Bożego miłosierdzia w życiu świętych. Przede wszystkim wspomniał Matkę Miłosierdzia, pisząc: „Wszystko w Jej życiu zostało ukształtowane przez obecność miłosierdzia, które stało się ciałem. Matka Ukrzyżowanego i Zmartwychwstałego weszła do sanktuarium miłosierdzia Bożego, ponieważ wewnętrznie uczestniczyła w tajemnicy Jego miłości”59. Teologowie podkreślają działanie miłosierdzia Bożego w życiu Maryi ukazane szczególnie w ewangelicznych opisach jej powołania (por. Łk 1, 26-38), w hymnie Magnificat (por. Łk. 1, 46-55)i w Chrystusowym testamencie spod Krzyża (por. J 19, 25-27).

55 Por. Benedykt XVI, Deus caritas est, 26; Caritas in veritate, 6, 79; A. Elsässer, Barmherzigkeit, dz. cyt., k. 15n.

56 Por. J. Krucina, Komentarz do encykliki Jana Pawła II „Dives in misericordia”, [w:] Encyklika Ojca Świętego Jana Pawła II o Bożym Miłosierdziu „Dives in misericordia”, Wrocław 1996, s. 94.

$57 \mathrm{MV}, 15$.

58 Por. Kongregacja do Spraw Wychowania Katolickiego, Wskazania dotyczace studiów i nauczania doktryny społecznej kościoła w ramach formacji kapłańskiej, 1988, nr 7.

59 MV, 24. 
Prawda o Matce Miłosierdzia znalazła swój wyraz w wielu źródłach teologicznych, w tym głównie w znanych modlitwach: Sub Tuum Praesidium i Salve Regina ${ }^{60}$.

Oprócz przywołania Najświętszej Maryi Panny, bulla papieska odnosi się do rzeszy pozostałych czcicieli Bożego miłosierdzia. W dokumencie czytamy:

Nasza modlitwa rozciąga się również na wielu Świętych i Błogosławionych, którzy uczynili z miłosierdzia swoją misję życia. W sposób szczególny myśl kieruje się ku wielkiej apostołce miłosierdzia, świętej Faustynie Kowalskiej. Ta, która została wezwana do wejścia w głębokości Bożego miłosierdzia, niech wstawia się za nami i uzyska dla nas łaskę życia i chodzenia zawsze w świetle Bożego przebaczenia oraz w niezachwianej ufności w Jego miłośćc1.

Z analizy Dzienniczka świętej siostry Faustyny Kowalskiej wynika potrzeba poznania prawdy o Bożym miłosierdziu, zawierzenia Bożemu miłosierdziu, modlitwy o miłosierdzie i oddania czci Bogu w tej tajemnicy, oraz kształtowania postaw i świadczenia czynów miłości miłosiernej ${ }^{62}$. Różne formy kultu Boga bogatego w miłosierdzie mają na celu uwielbienie Go i zbliżenie ludzi do Niego, oraz otwarcie ich na działanie łaski, którą miłosierny Jezus pragnie każdego obdarzyć. Do podstawowych form kultu przekazanych przez świętą Faustynę należy uczczenie obrazu Jezusa Miłosiernego, obchodzenie święta Bożego miłosierdzia oraz różne modlitwy do Bożego miłosierdzia, głównie koronka, nowenna i akty strzeliste, odmawiane szczególnie o godzinie piętnastej. Trzeba też dodać do tego duchową lekturę Dzienniczka, który może być cenną podstawą do medytacji ${ }^{63}$. Szczególną duchową więzią z tajemnicą Bożego miłosierdzia żyło wielu świętych, spośród których papież Franciszek wyróżnił właśnie świętą Faustynę Kowalską, „sekretarkę" Bożego miłosierdzia. Obok niej na uwagę zasługuje błogosławiony ksiądz Michał Sopoćko, który znał wcześniej teologiczną refleksję o przymiotach Boga, jednak krzewicielem kultu Bożego miłosierdzia został dopiero pod wpływem duchowych rozmów prowadzonych z siostrą Faustyną, poznaną przez niego w 1933 roku $^{64}$.

Wielu świętych zasłynęło też z postawy miłosierdzia, której szczególnym wzorem w naszej polskiej duchowości jest święty brat Albert Chmielowski ${ }^{65}$. Troska o ubogich doprowadziła go ostatecznie do poświęcenia im swego życia i stania się

${ }^{60}$ Por. K. Wendlik, Maryja jako Matka Miłosierdzia w aspekcie jej ipsissima verba et facta oraz źródeł teologicznych z I tysiąclecia, „Łódzkie Studia Teologiczne” 24 (2015) 4, s. 99-110.

${ }^{61} \mathrm{MV}, 24$.

62 Por. W. Słomka, Miłosierdzie Boże..., dz. cyt., s. 523.

63 Por. J. Machniak, Doświadczenie Boga..., dz. cyt., s. 279, 288.

${ }^{64}$ Por. S. Wiśniewski, Błogosławiony ks. Michał Sopoćko. Kapłan o miłosiernym obliczu, „Łódzkie Studia Teologiczne” 24 (2015) 4, s. 113.

${ }_{65}$ Por. M. M. Wójtowicz, Miłosierdzie w postawie błogosławionego brata Alberta, [w:] Homo Meditans, t. 5, dz. cyt., s. 217n. 
mnichem w zgrzebnym tercjarskim habicie. To przeobrażenie nastąpiło dnia 25 sierpnia 1887 roku w kaplicy loretańskiej u ojców kapucynów w Krakowie. Wraz z habitem Adam przyjął imię brat Albert. Poprzez swoich podopiecznych, których przygarnął jeszcze w pracowni malarskiej przy ulicy Basztowej 4, zaraz po przyjeździe z Podola, trafił do miejskiej ogrzewalni dla mężczyzn przy ulicy Piekarskiej 21. Jej potworna moralna i materialna nędza, nieludzkie warunki życia jej w dużej mierze zdemoralizowanych mieszkańców zrodziły ostateczną decyzję, by pośród nich zamieszkać. Aby móc z całą swobodą poświęcić się służbie ubogim, dnia 25 sierpnia 1888 roku złożył na ręce biskupa krakowskiego Albina Dunajewskiego dozgonny ślub czystości. Dzień ten uważany jest za datę powstania Zgromadzenia Braci Albertynów ${ }^{66}$. Karol Wojtyła w dramacie Brat naszego Boga ukazał ewolucję duchową Adama Chmielowskiego, który zaczyna pojmować istotę prawdziwej, ewangelicznej rewolucji społecznej, mówiąc: „Bo ja - to prawda - ja chciałem się wykupić... tu jakieś palto, tam jakiś bochen chleba, tu ktoś na nocleg... A to wszystko nic nie znaczy... bo tak zostają ciągle dziady, łachmaniarze, ulicznicy... [...] A mają być bracia!"' ${ }^{6}$. Fenomen brata Alberta polega bowiem na tym, że nie tylko służył ubogim, ale sam stał się jednym z nich, skoro oni stali się dla niego żywą ikoną Chrystusa - Ecce Homo. Było to głębokie przeżycie prawdy Chrystusowych słów: „Wszystko, co uczyniliście jednemu z tych braci moich najmniejszych, Mnieście uczynili” (Mt 25, 40) ${ }^{68}$.

W skali całego Kościoła powszechnego szczególnego znaczenia nabrały dzieła miłosierdzia takich postaci, jak św. ojciec Pio i św. MatkaTeresa z Kalkuty, której kanonizacja nastąpiła 4 września 2016 roku, jako jedno z najważniejszych wydarzeń Roku Miłosierdzia. To tylko dwa wymowne przykłady na to, że wiele męskich i żeńskich wspólnot zakonnych odwołuje się w swej duchowości i nazwie do tajemnicy Bożego miłosierdzia ${ }^{69}$.

\section{Zakończenie}

Ogłoszona przez papieża Franciszka 11 kwietnia 2015 roku bulla Misericordiae Vultus, zapowiadająca Nadzwyczajny Jubileusz Miłosierdzia, przypomniała, że

66 Por. S. Karmela Banaszczuk, Świadectwo oddania bez reszty. Przemówienia, homilie i utwory Karola Wojtyly - kapłana, biskupa, kardynała i papieża o Bracie Albercie - Adamie Chmielowskim, Kraków 1990, s. 11; J. Żak-Tarnowski, Brat Albert, Warszawa 1973, s. 101.

${ }^{67}$ K. Wojtyła, Brat naszego Boga, [w:] tenże, Poezje i dramaty, Kraków 1980, s. 150.

68 Por. Jan Paweł II, List na 150-lecie urodzin św. Brata Alberta Chmielowskiego (6.01.1995), 1, „L'Osservatore Romano”(wyd. polskie), 3 (1995) 171, s. 60n.

69 Por. K. S. Frank, Barmherzigkeit, V: Ordensgenossenschaften, [w:] Lexikon für Theologie und Kirche, t. 2, dz. cyt., k. 16n; Barmherzige Brüder, Barmherzige Schwestern, [w:] Lexikon für Theologie und Kirche, t. 2, dz. cyt., k. 11-13. 
miłosierdzie ma swoje czasy. Dniem miłosierdzia jest każda niedziela i wszystkie dni pokutne, ale szczególnie druga niedziela Wielkanocy ustanowiona dla Kościoła polskiego przez Jana Pawła II w 1995 roku świętem miłosierdzia, rozciągniętym następnie w 2000 roku na cały Kościół. Oprócz dni miłosierdzia liturgia Kościoła zna także godziny miłosierdzia, spośród których szczególne znaczenie ma godzina piętnasta, jako godzina śmierci Chrystusa. Kościół przejął też z tradycji Starego Testamentu ideę jubileuszów, odniesionych do zbawczych wydarzeń Chrystusa i świętowanych szczególnie uroczyście w rytmie pięćdziesięciolecia, nawiązującym do roku miłosierdzia ${ }^{70}$. $Z$ tą tradycją wiążą się również nadzwyczajne jubileusze, takie właśnie jak Jubileusz Miłosierdzia. Przypomniał on Kościołowi i światu prawdę o Bożym miłosierdziu, którego oblicze ukazał Chrystus i które winno stale działać w Kościele, by poprzez świadectwo świętego życia chrześcijan promować cywilizację miłości i w ten sposób skutecznie głosić Ewangelię.

\section{Abstract \\ Theological and spiritual dimension of mercy according to bull Misericordiae Vultus of Pope Francis}

The author of the article analyses theological and spiritual dimension of mercy according to official bull of indiction of the Extraordinary Jubilee of Mercy. The bull is the fundamental document for the Holy See that outlines the intensions for the Jubilee. In the article we can find different meanings of the term 'mercy': the ancient use of the word by pagan philosophers, the analysis of the term 'mercy' in the Old and New Testament, the definition of dogmatic foundations of Divine Mercy, the ethical and moral aspects of the human mercy, as well as its social dimension. The author also deals with other dimensions of the mercy, such as: pastoral, liturgical and psychological. He also discusses the meaning of the mercy in the spirituality and Christian art.

70 Por. R. Forycki, Czas i czasy miłosierdzia, [w:] Bóg bogaty w miłosierdzie, dz. cyt., s. 332-335.

Ks. Wojciech Zyzak, Teologiczno-duchowy wymiar miłosierdzia w świetle bulli „Misericordiae Vultus” papieża Franciszka, [w:] Odsłony miłosierdzia, red. Zofia Zarębianka, Katarzyna Dybeł, Kraków 2017, s. 133-146 (Dni Jana Pawła II 2016).

http://dx.doi.org/10.15633/9788374386128.14 